CAHIERS

MONDES

ANCIENS

\section{Cahiers « Mondes anciens »}

Histoire et anthropologie des mondes anciens

$6 \mid 2015$

Mères grecques

\title{
The Myth of Mothers as Others
}

Motherhood and Autochthony on the Athenian Akropolis

L'exclusion des femmes - un mythe scientifique. Maternité et autochtonie sur

l'Acropole athénienne

\section{Viktoria Johanna Räuchle}

\section{(2) OpenEdition \\ Journals}

Édition électronique

URL : http://journals.openedition.org/mondesanciens/1422

DOI : $10.4000 /$ mondesanciens. 1422

ISSN : 2107-0199

Éditeur

UMR 8210 Anthropologie et Histoire des Mondes Antiques

Référence électronique

Viktoria Johanna Räuchle, « The Myth of Mothers as Others », Cahiers « Mondes anciens » [En ligne],

6| 2015, mis en ligne le 16 février 2015, consulté le 02 mai 2019. URL : http://

journals.openedition.org/mondesanciens/1422 ; DOI : 10.4000/mondesanciens. 1422

Ce document a été généré automatiquement le 2 mai 2019.

\section{(c) (i) (9)}

Les Cahiers «Mondes Anciens » sont mis à disposition selon les termes de la licence Creative Commons Attribution - Pas d'Utilisation Commerciale - Pas de Modification 4.0 International. 


\title{
The Myth of Mothers as Others
}

\author{
Motherhood and Autochthony on the Athenian Akropolis \\ L'exclusion des femmes - un mythe scientifique. Maternité et autochtonie sur \\ l'Acropole athénienne
}

Viktoria Johanna Räuchle

\section{Autochthony, a misogynistic concept?}

1 In the fifth century $\mathrm{BC}$, the Athenians were obsessed with their autochthony. Being autochthonous comprised two notions: firstly, the idea of always having inhabited the same land and, secondly, the idea of literally being born from the soil (on the Athenian concept of autochthony see e.g. Rosivach 1987; Loraux 1993, p. 37-43; Shapiro 1998, p. 130-131; Sourvinou-Inwood 2010, esp. p. 65. 83). Although invented at an earlier date, a fully formed notion of autochthony only developed in the fifth century in response to the needs of the young democracy. Alan Shapiro distinguishes two functions of autochthony:

On the one hand, autochthony is, like democracy itself, a great leveller. It asserts

that every native Athenian is as good as every other, by virtue of their common ancestry going back to Erechtheus. [...] At the same time, autochthony also implies that the Athenians are an older, purer, and nobler race than other Greeks, and hence natural born leaders of an alliance (Shapiro 1998, p. 131).

2 Autochthony is hence an old concept which was revived during the fifth century to create a common identity within the democratic community while at the same time confirming a natural superiority over non-Athenians. It is as easy as that, there is no need to roll out other explanations. And yet in feminist scholarship, the Athenian claim for being autochthonous has been interpreted as a product of an androcentric perspective and, more precisely, as a means of eliminating female agency from the process of procreation. For instance, according to Nicole Loraux, the role of the earth goddess Ge as the mother of Erichthonios "dépossède les femmes d'Athènes de leur fonction reproductrice" (Loraux 1981, p. 12. For further quotes see: Calame 2011; Detienne 2003, p. 39-43). This reading of the myth is embedded in an overall conception of Athens as a radically patriarchal and misogynous system that programmatically excludes its women from civic 
identity: “Il n'y a pas de première Athénienne, il n'y a pas, il n'y a jamais eu d'Athénienne" (Loraux 1981, p. 13).

3 Only recently, scholars have started to challenge this perspective in favor of a more comprehensive view on the principles of myth making. Violaine Sebillotte Cuchet (2005) has rightly pointed out that the role of Ge as mother of all Athenians is not the result of the battle between the sexes but has to be understood as a means to connect the Athenians (men and women) as strongly as possible to the land they inhabit. Claude Calame too has argued against this biased approach towards autochthony by discussing the role of Praxithea and her daugthers within the symbolic creation of civic identity. In his reading of Euripides' Erechtheus, Calame states:

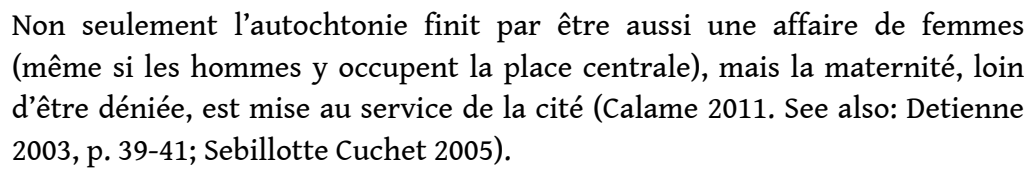

In the present paper, I would like to elaborate on these arguments from an archaeological perspective and take a closer look at the ways in which motherhood was conceptualized in the public imagery of classical Athens. An iconographic and contextual analysis of visual representations will demonstrate that Athenian wives and mothers were far from being excluded from the political sphere but, on the contrary, were assigned a prominent role in the "public" face of the polis. The study shall concentrate on three case studies: The first part deals with the birth of the autochthonous king Erichthonios in classical Athenian vase-painting. Here, I am particularly interested in the rendering of maternal qualities in both Ge and Athena and what it reveals about the role of motherhood in the construction of Athenian civic identity. The second part of the argument will look at the frieze of the Erechtheion: from the late fifth century onwards, this particular building was the religious center of the Athenian Akropolis and comprised some of the most ancient and holy cult sites of Athens. Its beautiful yet very fragmented frieze depicts various female figures and mothers that will be interpreted against the background of Athenian genealogy and the symbolics of autochthony. The third case study will look at the famous statue group of Prokne and Itys which was erected on the Akropolis in the late fifth century BC and which hints at a new understanding of maternity and maternal sacrifice in the turmoil of the Peloponnesian war.

\section{The two mothers of Erichthonios}

Besides the primordial snake-footed king Kekrops, the Athenian king Erichthonios, born from the earth-goddess Ge and raised by Athena, is the most important figure in the mytho-historical construction of Athenian autochthony. The story of his birth unites different concepts of motherhood and thus serves as an ideal starting point to get an idea about the roles of Athenian mothers within the framework of fifth century BC politics and nationalism.

There are various versions of this mytheme but by the time of the second half of the fifth century, the course of events as later reported in the Bibliotheka by Apollodorus (3.14.6), seems to have become the dominant one: One day, Athena visits Hephaestus to order some weapons. Overwhelmed by lustful intentions, the crippled smith starts to importune Athena and eventually gushes his seed over her thigh. ${ }^{1}$ Athena wipes it off with a piece of 
wool, tosses it on the ground, and thus impregnates the earth, Ge. ${ }^{2}$ After giving birth to Erichthonios, Ge entrusts the newborn to Athena who puts him in a box with two guardian snakes and hands him over to the daughters of Kekrops - with the warning not to open it. ${ }^{3}$ Two of the three daughters cannot resist their "innate female curiosity", open the chest, are driven mad, and leap from the Akropolis. Erichthonios is then brought back to Athena and raised by her in her very own temple.

7 This is everything we know from the life of Erichthonios. Until the fifth century BC, he was identical with Erechtheus, the mythical protagonist in the so-called Eleusinian war (on his myth see below). Only by the beginning of the fifth century, Erichthonios/ Erechtheus was split into two distinct personalities: Erichthonios now assumed the role of the earth-born child while Erechtheus became the adult king who saves Athens. The complex and controversial scholarly debate about their original identity and the reasons for the fission cannot be discussed here. ${ }^{4}$ Instead, I would like to focus on the visual representations of Erichthonios and his "two mothers". His birth and early life are subject to several vase paintings. While the written sources are very scattered and ambiguous, these paintings are the most concrete sources we have on the miraculous king in the fifth century BC. ${ }^{5}$

At least 16 vases depict the birth of Erichthonios, the lion's share of which is dated to the second half of the fifth century. ${ }^{6}$ Apart from an early predecessor, ${ }^{7}$ all images follow the same iconographic schema: To the left, we always see Ge emerging from the ground and handing over Erichthonios to Athena. Further figures may be added: grandfather Zeus, father Hephaistos, the primordial Athenian king Kekrops, often depicted with the body of a snake to underline his bestial nature, or his daughters who will open the chest in the course of the story. All of them allude to one of the many genealogical interrelations within the story and serve to create an aura of solemn festivity. ${ }^{8}$ 
Fig. 1: The birth of Erichthonios

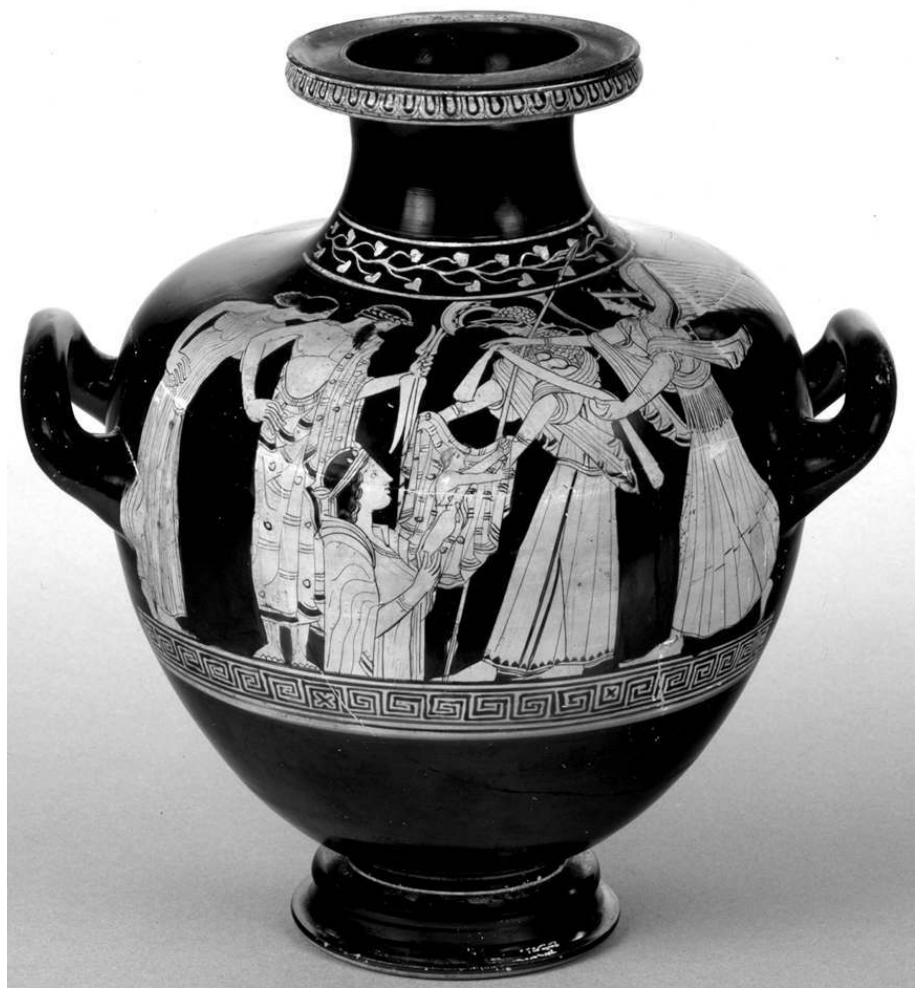

Att. rf. hydria, 470-460 BC, Oinanthe painter. London British Museum E182. (c) Trustees of the British Museum.

Fig. 2: The birth of Erichthonios

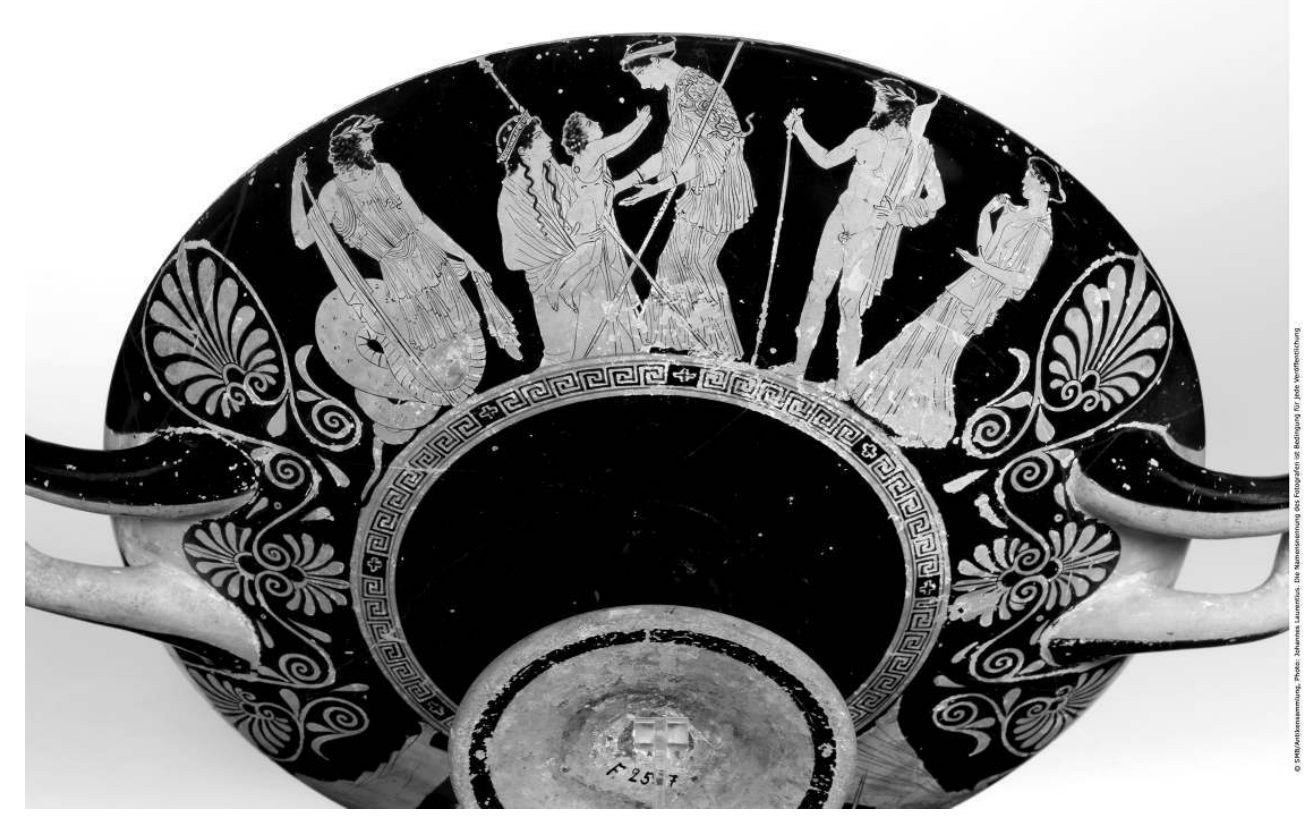

Att. rf. kylix, 440-430 BC, Berlin SMPK F 2537. @ Staatliche Museen zu Berlin, Antikensammlung, photo: Johannes Laurentius. 
For the sake of the argument, I will focus on the central group of Athena, Ge, and Erichthonios. An early rendering of the mytheme can be seen on a hydria in London (Fig. 1): 9 Athena is fully armed, illustrating her martial nature. With Athena's father Zeus being present and Nike bringing a victory sash for the newborn, all elements allude to the divine ancestry and the glorious future of little Erichthonios. In the subsequent years, Athena's appearance as well as her interaction with Erichthonios become more and more tender and motherly: on a cup in Berlin (Fig. 2), ${ }^{10}$ the tutelary goddess stretches out her arms to receive the little boy; she has even turned her aegis onto her back in order not to frighten him. Erichthonios leans towards her and stretches out his arms.

This so-called "longing gesture" is the most typical gesture for little children in classical art (cf. Dickmann 2006, p. 467). Firstly, it visualizes their basic need for attention and care; secondly, it indicates that the child recognizes the person thus addressed as an attachment figure. In many cases, this person acknowledges the child's need by stretching out both arms in a welcoming gesture.

11 Thus, there is no doubt that the virgin goddess is characterized as the main attachment figure for Erichthonios: the images clearly establish an exclusive dyadic relationship between Athena and Erichthonios. Yet, the exact nature of this relationship is still subject of controversies. Ernst Curtius (1873, p. 53) already pointed out the strong symbolic compliances these images share with the ancient ritual of amphidromia, when the kyrios, usually the father, picks up the newborn from the ground, i.e. the earth, carries it around the hearth, and thereby accepts it as an official member of the household. Henri Metzger elaborated on this interpretation by comparing Athena's role in the myth of Erichthonios with the function of Levana, the Roman goddess for protecting newborns. ${ }^{11}$ Nicole Loraux went one step further and claimed that the conjectural innuendos to the amphidromia had to be understood as a means to construct Athena as the social father for Erichthonios:

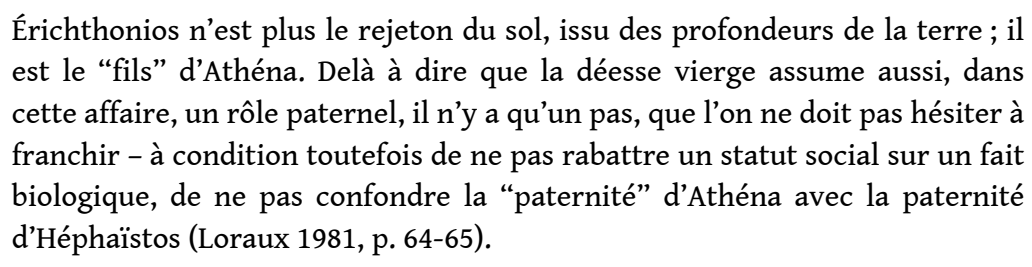

In order to really understand the interaction between Athena and Erichthonios in these images, we have to adopt an iconographic approach and take a closer look at mythical and non-mythical representations in which a similar interaction between a parental figure and a child is established. Nicole Loraux cited some images of Achilles being brought to the centaur Chiron in order to substantiate her interpretation of Athena as a paternal figure: On an archaic black-figure Amphora in Baltimore, Achilles is handed over by Peleus to his beastly teacher while looking at his father and stretching out his arms towards him. Here the interaction pattern of "longing and receiving" takes place between father and son (att. bf. amphora, ca. 520-500 BC, Baltimore The Walters Art Museum 48.18; $\mathrm{BA}^{\circ}$. 320360; ABV 288, 13). 


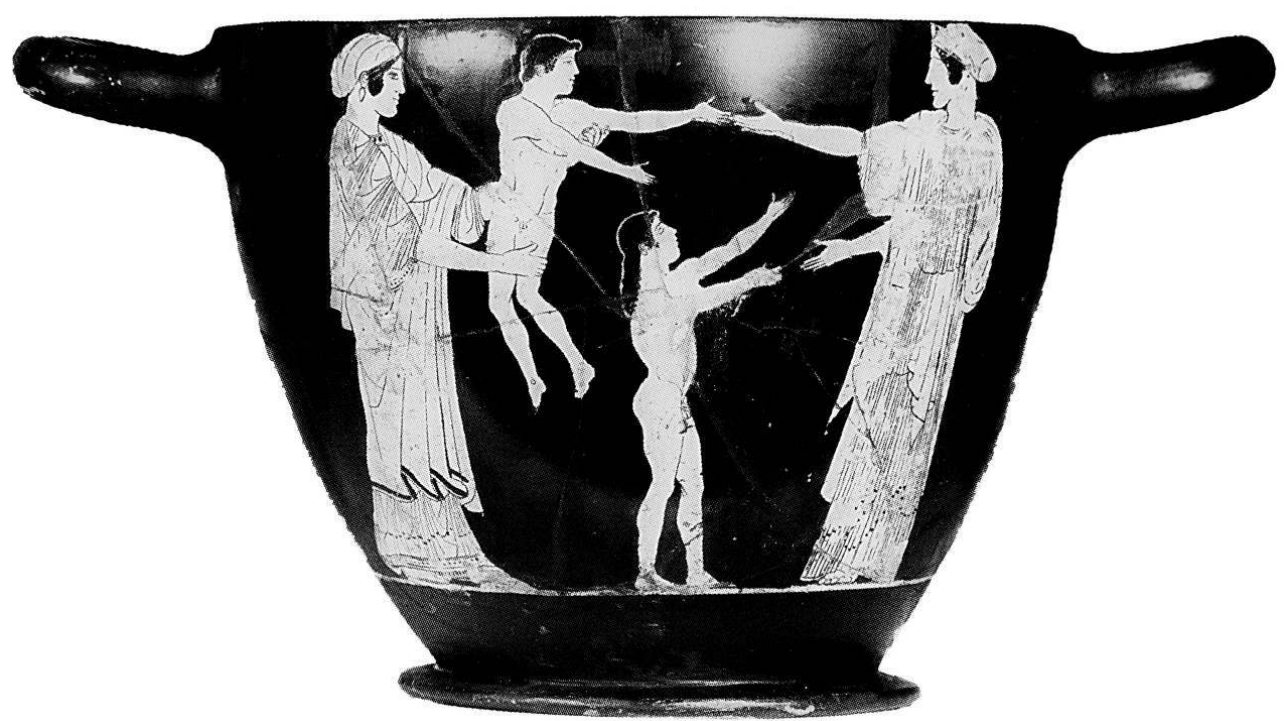

Att. rf. skyphos, around 450 BC, Vienna KHM 1773. Photo: after Shapiro 2003, p. 95, fig. 11b

But this is certainly not the only constellation in which this gestural interaction is represented. On a skyphos in Vienna, for instance, Ariadne entrusts her little sons Eunopion and Staphylos to a nymph (Nú $u \varphi \varepsilon$ ) who is going to take care of them (Fig. 3). ${ }^{12}$ The boys, one is already standing while the other one is still carried by his mother, stretch out their arms towards the nymph and therewith accept her as their new caregiver. Further evidence comes from some interesting votive reliefs that were dedicated by mothers to kourotrophic deities for the protection of their children. One of the finest examples is an Attic votive relief donated by Xenokrateia to Kephisos and other deities for the education of her son Xeniades. ${ }^{13}$ The relief shows the donator and her offspring as short mortal figures amidst the divine assembly. They are approaching the young river god Kephisos who bends over towards them. Xenokrateia raises her arms and extends her hands with open palms, a typical gesture of veneration. Her son, nude and facing the interior of the relief with his body in a three-quarter turn away from the viewer, raises and extends his right arm toward Kephisos. By this longing gesture, Xeniades recognizes the river god as his protector.

It is now possible to draw a first preliminary conclusion: the interaction pattern of "longing and receiving" visualizes some sort of reciprocal recognition. Applied to Erichthonios, this means that Athena accepts the earth-born as her "protégé", while he accepts her as his new attachment figure (cf. Loraux 1981, p. 64; Shapiro 1998, p. 135; Darthou et Strawczynski 2006, p. 58). However, on the basis of the mythical images alone, the gestural interaction pattern does not provide any information about the exact relation between the child and the adults holding respectively receiving it and can be used to characterize a large variety of (family) constellations.

15 In order to gain more clarity about the nature of these relations, we have to consult images of the Athenian "Lebenswelt", i.e. mortal protagonists in idealized illustrations of everyday life. Here, we do find some interesting tendencies with regard to the standard constellation of this motif. The most common context for the interaction pattern of "longing and receiving" is the gynaikonitis, the women's quarters. In these domestic 
scenes, one woman can often be identified as the "lady of the house" through her sitting position and through other female characters attending her. In some scenes, a little child, usually a boy, is depicted to further characterize her as "mother" and thus visualize her qualities as producer of legitimate male children. There are 23 domestic scenes on attic vase paintings that depict one or more women with a (male) infant or toddler (see Crelier 2008, p. 262-275). In the majority of these scenes, the interaction pattern of "longing and receiving" takes place between mother and child while the nurse/attendant carries it on her arms (Tab. 1). ${ }^{14}$

\begin{tabular}{|l|l|l|l|l|l|}
\hline & mother & female attendant & woman unclear & father & total \\
\hline child carried by & 4 & 8 & 3 & - & 15 \\
\hline child longing for & 16 & 1 & 1 & 1 & 19 \\
\hline child received by & 11 & 1 & - & - & 12 \\
\hline
\end{tabular}

Fig. 4: Mother, nurse, and child

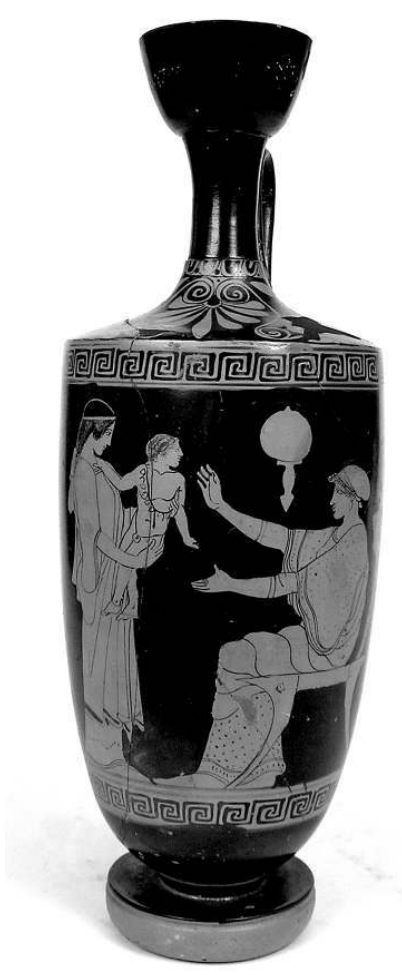

Att. rf. lekythos, painter of Bologna 228, 475-450 BC, Athens NM 1304. @ Hellenic Ministry of Culture and Sports /Archaeological Receipts Fund. National Archaeological Museum, Athens, photo: Irini Miari.

A lekythos in Athens shall illustrate the standard composition (Fig. 4): ${ }^{15}$ the female protagonist and thus "mother" is sitting on her chair, while another female, characterized as parthenos by a long braid falling down her neck, carries around a little naked boy. He is wearing an apotropaic amulet - reminiscent of Erichthonios' two snakes (cf. Euripides Ion 20-27. 1427-1432) - and stretching his arms towards his mother who in turn is receiving him with a welcoming gesture. The same composition can be found on 
Athenian grave reliefs: The infant is almost always carried around by a female companion, while the mother interacts with her offspring through gestures and eye contact, just like Athena. These images provide a clear message: The menial, i.e. physical, tasks of child care are outsourced to nurses, whereas Athenian mothers are first and foremost characterized as mental attachment figures for their children.

17 These domestic scenes occur much more frequently than the mythical images with similiar interaction patterns and should therefore be understood as the archetype of this motif. The relationship between a mortal mother and a child is the role model for the gestural interaction of "longing and receiving". A passage in Euripides' Ion provides further evidence for the validity of this interpretation. When Kreusa tells her old tutor how she exposed her little son Ion, she describes her parting with the following words:

Creusa: If you had seen the child stretch out his hands to me!

Tutor: Seeking the breast, or reaching for your arms? Creusa

Creusa: Here, where he suffered wrong from me, being absent from my arms. ${ }^{16}$

18 Against this backdrop, the interpretation offered by Curtius and others according to which the images of Erichthonios' birth allude to the amphidromia has become highly unlikely. There is not a single image of this ritual that could be consulted for an iconographic comparison, nor do the written sources suggest this reading. Loraux'understanding of Athena as the "social father" of Erichthonios and, subsequently, all Athenians has to be dismissed as well: the goddess is depicted in an iconography typical for Athenian mothers.

To sum it up, the myth of Erichthonios comprises two different aspects of motherhood: a physical one, embodied by the earth $\mathrm{Ge}$, and a social one, embodied by the virgin goddess Athena. ${ }^{17}$ Even if one admits that the figure of Athena also conveys some male or even paternal qualities, she is first and foremost characterized as a maternal attachment figure for the little boy.

\section{Mothers on the Erechtheion}

20 As could be demonstrated, the visual implementations of the birth of Erichthonios, this pivotal myth with regard to the Athenian claim for autochthony, comprised not only one, but two different concepts of motherhood. On the other hand, the paternal principle, embodied by the begetter Hephaestus and, on a rather subtle level, by the figure of Athena, only played a minor role.

21 Another way of approaching the issue of motherhood and autochthony is to look at the representations of maternal figures within the city's public spaces. In the Periclean building program on the classical Akropolis, mothers and kourotrophoi are represented in the pediments and the frieze of the Parthenon, in the sculptural program of the Erechtheion, in decorative paintings, in free-standing statues and statue groups; in short: they were an integral part of the public self-representation of the city. Thus, with regard to the maternal figures in the Western pediment of the Parthenon, Burkhard Fehr rightly observes:

The women are clearly in the majority in comparison to the men; the considerable number of children is also noteworthy. This is to show that the mythical Athenian community distinguished itself through exemplary wives and mothers who fulfilled their obligations toward the polis by bearing and raising auspicious offspring (Fehr 2011, p. 136). 
In the context of the present case, the enigmatic frieze of the Erechtheion deserves particular attention: Although its exact topic is lost, it still offers a variety of possibilities for motherhood to be conceptualized visually. The Erechtheion was built between 438 and $406 \mathrm{BC}^{18}$ and incorporated numerous cult sites of Athenian heroes and divinities including Athena, Poseidon, Kekrops, Boutes, Pandrosos, and Erechthonios/Erechtheus himself. It also housed some of the most sacred relics of the Athenians, such as the ancient cult statue of Athena (the palladion), Poseidon's salt water well, and Athena's holy olive tree. All these cult places existed long before the Erechtheion, but were now united under one roof for the very first time (alas, "the exact location of the cults within the temple is uncertain", Goette 2001, p. 26). While the Parthenon may have served as the main temple for Athen's civic identity, the Erechtheion was the religious core of the city.

The main building and the North porch were surrounded by a frieze of fully carved marble figures, 80 percent of which have survived at least in fragments (Lesk 2004, p. 120). Besides the preserved originals, there are several building accounts of the Erechtheion that list some of the sculptures created for the temple in the form of short descriptions together with the executing sculptor and his payment. Despite this exceptionally dense documentation, it has not yet been possible to identify even one of the depicted (mythical) personae, not to mention the exact iconographic program..${ }^{19}$ Only a few scholars have so far ventured on the difficult task of hypothesizing about the iconographic program. ${ }^{20}$

Fig. 5: Group of the Erechtheion frieze (fragment)

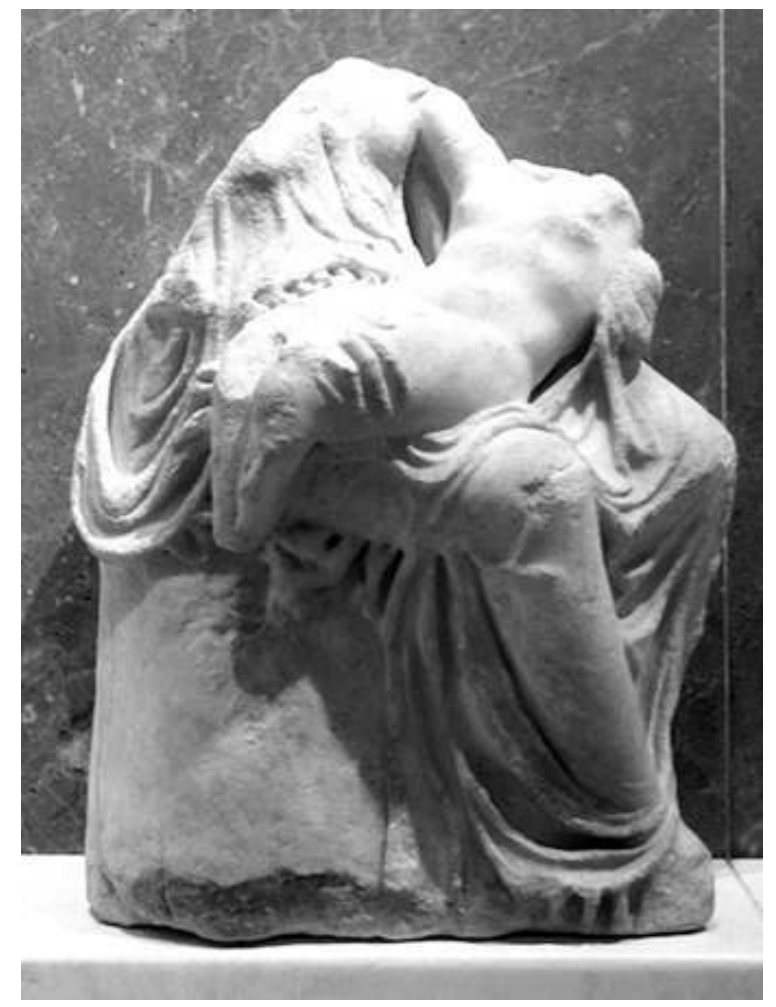

409-406 BC, Akropolis Museum Acr. 1075. (C) Acropolis Museum 


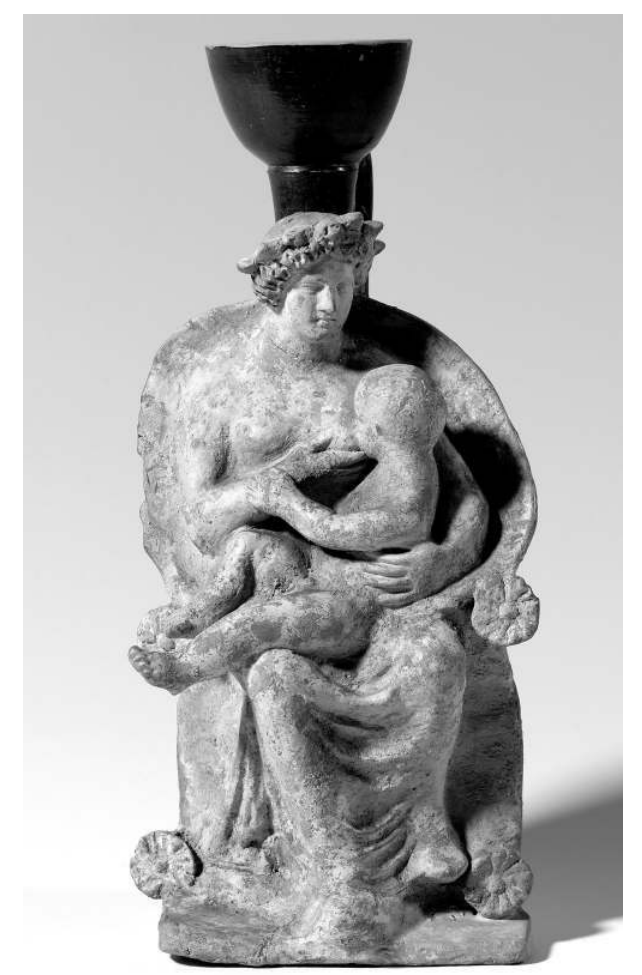

Att. plastic lekythos, 4th century BC, from Corinth, Berlin SMBK F 2913. @ Staatliche Museen zu Berlin, Antikensammlung, photo: Johannes Laurentius.

The overwhelming majority of the surviving figures are female. Some of them are carrying a child on their lap or are otherwise adopting a maternal habitus. This prevalence of female and especially maternal figures leaves no doubt that the frieze conveyed a genealogical message and aimed at praising the exemplary mothers and venerable offspring of the Athenians. This becomes apparent in two fragmented statue groups of the kourotrophic type. The better preserved Acr. 1075 shows a matronal woman in chiton and himation sitting to the right and holding a naked boy on her lap (Fig. 5). She grasps the child with both arms who in turn puts its arms around her neck. The very poorly preserved group Acr. 1237 is the mirror-inverted version of Acr. 1075. The calm, almost enthroned posture of these female figures as well as the sharp contrast between their massive bodies and the "petite taille" of the naked boys suggest that these groups can be interpreted as kourotrophic figures: they were not part of a mythological narrative, but featured as independent emblemata without an active role in any specific story. The kourotrophos is featured in numerous terracotta figurines and has to be understood as generic symbol for the female task of breeding and nurturing, or as "a manifestation of the mother- or nursing-principle" (Hadzisteliou-Price 1978, 2; cf. fig. 6). ${ }^{21}$

Besides these undefined epitomes of maternity, the frieze also contains several dynamic figures that were more likely part of a mythical narrative. Yet the exact matter of this narrative is still subject of wild speculations. Already in 1890, Carl Robert made the earliest but nevertheless most convincing suggestion. Based on the evidence of both building accounts and fragments, he claimed that the frieze must have depicted scenes of the Eleusinian war: 
So reich der Mythenkranz ist, der Athens heiligste Stätte, das Erechtheion, umwebt, so enthält er doch nur eine Sage, die von Krieg und Sieg berichtet, den Kampf des Erechtheus mit Eumolpos. Aber keine Sage hatte auch größeres Recht, an dem Tempel, an dem Erechtheus auf demselben Altar mit Poseidon die Opfer seiner Athener empfing, verherrlicht zu werden. ${ }^{22}$ of the Erechtheion frieze. ${ }^{23}$ Erechtheus is not only the eponymous hero of the temple, but his story also fits well with the preserved fragments of the frieze and the evidence from the building accounts. The most important episode of Erechtheus' life is the Eleusinian war. It was told at length in Euripides' now lost tragedy Erechtheus, premiered in the City Dionysia in the year $422 \mathrm{BC}$ (on the dating of the play see: Clairmont 1971, p. 485; Webster 1967, p. 127): Eumolpos, a Thracian son of Poseidon and king of Eleusis, threatens to take control of Athens. Erechtheus consults an oracle how to avert the hostile takeover and is told that the only way to win victory is to sacrifice his youngest daughter. He and his wife Praxithea then jointly decide to kill the maiden for the sake of the city. According to some versions, their other two daughters commit suicide because of an oath that they would die together. Athens indeed wins the war albeit Erechtheus is struck by Poseidon's trident on the Akropolis, in fact on the very spot of the later Erechtheion. In the end, Praxithea is installed by Athena as her first priestess.

Fig. 7: group of the Erechtheion frieze (fragment)

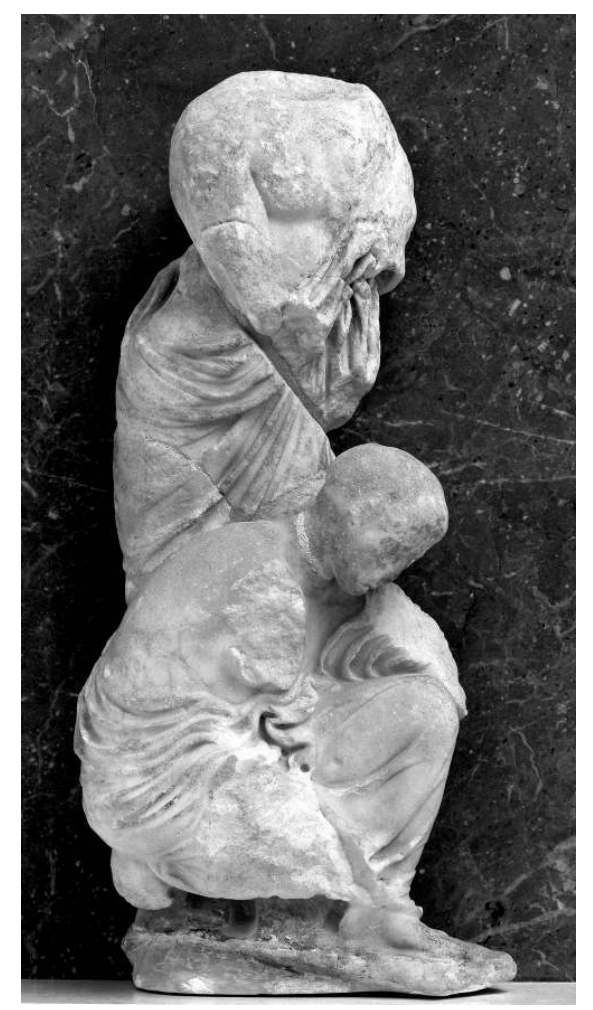

409-406 BC, Akropolis Museum Acr. 1073. @ Acropolis Museum, photo: Socrates Mavrommates 
Fig. 8: group of the Erechtheion frieze (fragment)

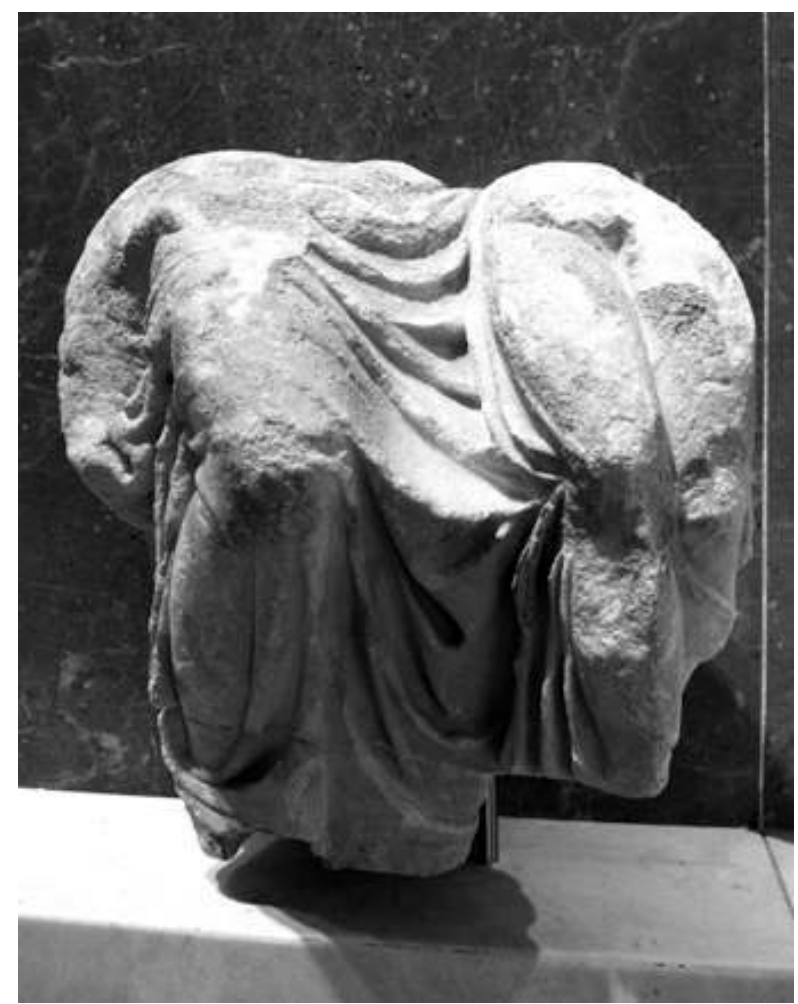

409-406 BC, Akropolis Museum Acr. 8589. (C) Acropolis Museum

Fig. 9: reconstruction of the group

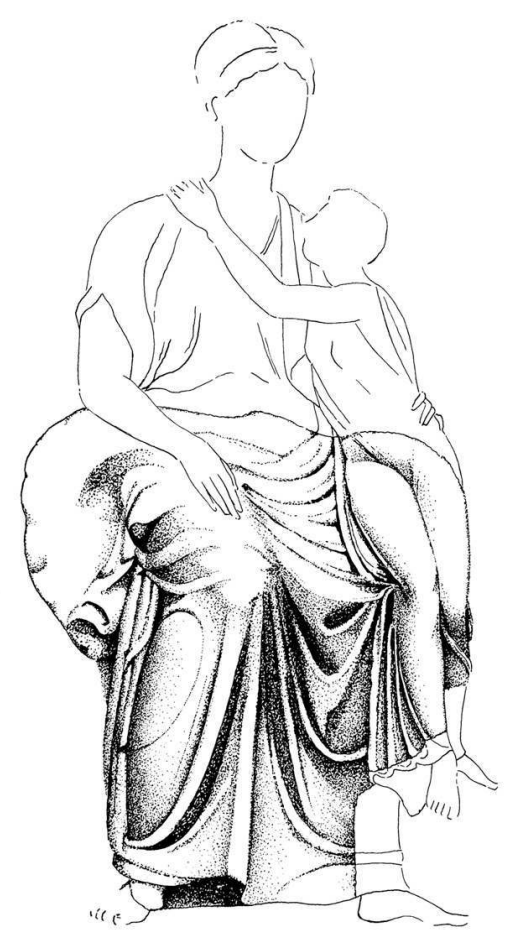

Acr. 8589. Drawing: Kostas Iliakis, after Daux 1968, p. 721, fig. 1 
Based on the extensive evidence in both the original pieces of the frieze and the building accounts, it can be argued that this mytheme was featured somewhere on the Erechtheion frieze. The building account IG I $\mathrm{I}^{3} 476$ informs us that the frieze depicted warriors and horse men preparing for a battle. It also mentions some very intriguing figures and groups that could have featured in the story of the Eleusinian war. The legible part of the inscription starts with a "youth writing and the man standing beside him". ${ }^{24}$ These lines have been convincingly identified with fragment Acr. 1073 that shows a young beardless man crouching next to a standing male figure (Fig. 7). ${ }^{25}$ Based on the iconographic comparison with plate 1 of the Telephos frieze of the Pergamon Altar where Aleos receives an oracle by Apollo, Carl Robert interpreted this scene accordingly as the recording of an oracle. ${ }^{26}$ This would be the first indication of the Eleusisian war. The account further mentions a wagon with mules, two women, and several men and youths arming themselves or harnessing their horses. ${ }^{27}$ The list concludes with some particularly interesting figures with regard to the present argument: a "man leaning on his staff besides an altar" and a "woman with the little girl leaning against her". ${ }^{28}$ Haido Koukouli correctly identified the second group with the fragment Acr. 8589 found on the Akropolis in 1978 (Fig. 8). The piece shows a sitting woman with a little girl on her lap. The woman is rendered in a very massive, matronal way and bears a little girl on her heavy thighs. Although the upper part of the group is missing, it is possible to draw some conclusions about its original appearance: The girl's feet were not reaching the ground, so she had to wrap her arms around the woman's neck in order to maintain her position. The folds of her delicate chiton also indicate that she was turning around towards the woman's body. A reconstruction by Kostas Iliakis suggests that she displayed a need for affection or even protection (Fig. 9). ${ }^{29}$

In other words, there is evidence for some of the constituent elements of the battle between Athens and Eleusis: Athenian warriors and horse men are preparing for their last fight; a male youth is writing down the oracle; and a woman is comforting a girl about to be sacrificed on the altar next to her. If we think this through to the end, fragment Acr. 8589 could be identified with Praxithea and her little daughter. In the tragedy Erechtheus by Euripides, Praxithea serves as the epitome of the good citizen wife who is dedicated to the well-being of the polis. In one of the remaining fragments (fr. 50 Austin $=$ fr. $360 \mathrm{~N}$, transl. by M. R. Lefkowitz), Praxithea sends out a clear statement in favor for a selfsacrificing spirit for the social collective:

Citizens, take advantage of the fruit of my labor pains, save yourselves, win victory! One life will not stop me from saving the city. O my country, I wish that all who dwell in you would love you as much as I do! Then we would live in you at our ease and you would not suffer any harm.

It is particularly interesting to note that Praxithea explicitely alludes to the pains of labor when she talks about the loss of her daughter. It is a widely known topos in ancient Greek literature to describe the ordeals of parturition in order to evoke maternal love: In the Nicomachean Ethics (1168a, transl. by H. Rackham), for instance, Aristoteles cites the unconditional love of mothers as an example for true philia and explains this specific female disposition with "biological" conditions:

This is why mothers love their children more than fathers: because parenthood costs the mother more trouble and the mother is more certain that the child is her own. 
The tragic women. Too, follow this notion of the child-loving mother as can be seen, for instance, in Euripides' Phoenician Women (355-356, transl. by E-P. Coleridge), when the chorus exclaims:

Their offspring are a powerful and painful thing to women;

And yet the whole species of women is child-loving in some way. ${ }^{30}$

The constant allusion to labour pains serves to testify the inseparable bond between a mother and her offspring. In these quotes, the physical act of giving birth is identical with maternal affection, an affection that lies beyond the rational and acts on mothers as an irresistible power. Against this backdrop, Praxithea's sacrifice becomes even more heroic: She values the common good over the life of her own child that she delivered in agony. In consenting to and even demanding the sacrifice of her beloved daughter, she keeps control over her maternal instincts and thus overcomes the biological restraints of the "species of women". The necessity for emotional self-restraint was eminent in the context of the political circumstances of the late fifth century: Between 431 and 404 BC, Athens was shaken by the Peloponnesian wars, which demanded the lives of thousands of Athenian sons and husbands. The "manifesto" of this ideology survives in the famous funeral speech of Perikles (Thukydides 2, 44, 3, transl. by B. Jowett), where he clearly summons both men and women to make sacrifices for the polis:

Some of you are of an age at which they may hope to have other children, and they ought to bear their sorrow better; not only will the children who may hereafter be born make them forget their own lost ones, but the city will be doubly a gainer. She will not be left desolate, and she will be safer. For a man's counsel cannot have equal weight or worth, when he alone has no children to risk in the general danger.

In this nexus, Praxithea's extreme attitude with regard to civic duties is indeed that of the ideal citizen woman. It would be only logical if her heroic deed for the polis was commemorated in the frieze of the Erechtheion: the very temple that housed the grave of her husband Erechtheus and that she guarded as the first priestess of Athena. ${ }^{31}$

\section{Prokne, the vengeful mother of Itys}

The political unrest of the second half of the fifth century was the ideal breeding ground for self-determined heroines - and mothers. To further strengthen this argument, we shall now turn to another myth full of blood, vengeance, and self-sacrifice that becomes an integral part of the Athenian past by the late fifth century BC: The myth of Prokne and Itys. The early written evidence is rather scarce, and a complete account of Prokne's story is only preserved in late accounts, Apollodorus' Bibliotheka (3.14.8) and Ovid's Metamorphoses $(6,424-674) .{ }^{32}$ Prokne is the older of two daughters of the great Athenian king Pandion and therefore, at least according to some sources, also the sister of Erechtheus. Following a well established custom of pre-democratic times, Pandion marries her off to the Thracian king Tereus in order to strengthen foreign political alliances. The young woman soon gives birth to a son, Itys, but nevertheless feels lonely among all the barbarians and therefore sends her husband to bring her younger sister Philomela to Thrace. Tereus does as instructed but is soon overrun by passion for his beautiful blossoming sister-in-law. After indulging his despicable desire, he cuts off her tongue and then locks her up in a secret chamber in order to conceal his shameful action. Mute Philomela manages to weave her story into a cloth (in an encoded form that can't be cracked by men) and send it to her sister Prokne. Prokne succeeds in freeing her sister, 
and together they make up a vicious plan to take vengeance on Tereus: During a festival in honor of Dionysos, she kills her own son with a sword and serves him, cut and cooked, to her gruesome husband. When he finds out about the main incredient of his dinner, he tries to kill the two sisters, but instead they are all turned into birds: Prokne turns into a nightingale who eternally mourns her death son; Philomela becomes a swallow who tonguelessly chirps and twitters, and Tereus becomes a hoopoe (or another avian predator), doomed to chase his avengers for all eternity. The ancient names of Prokne and Philomela allude to this last episode: Prokne is called aêdôn (nightingale), Philomela chelidôn (swallow).

Fig. 10: The murder of Itys

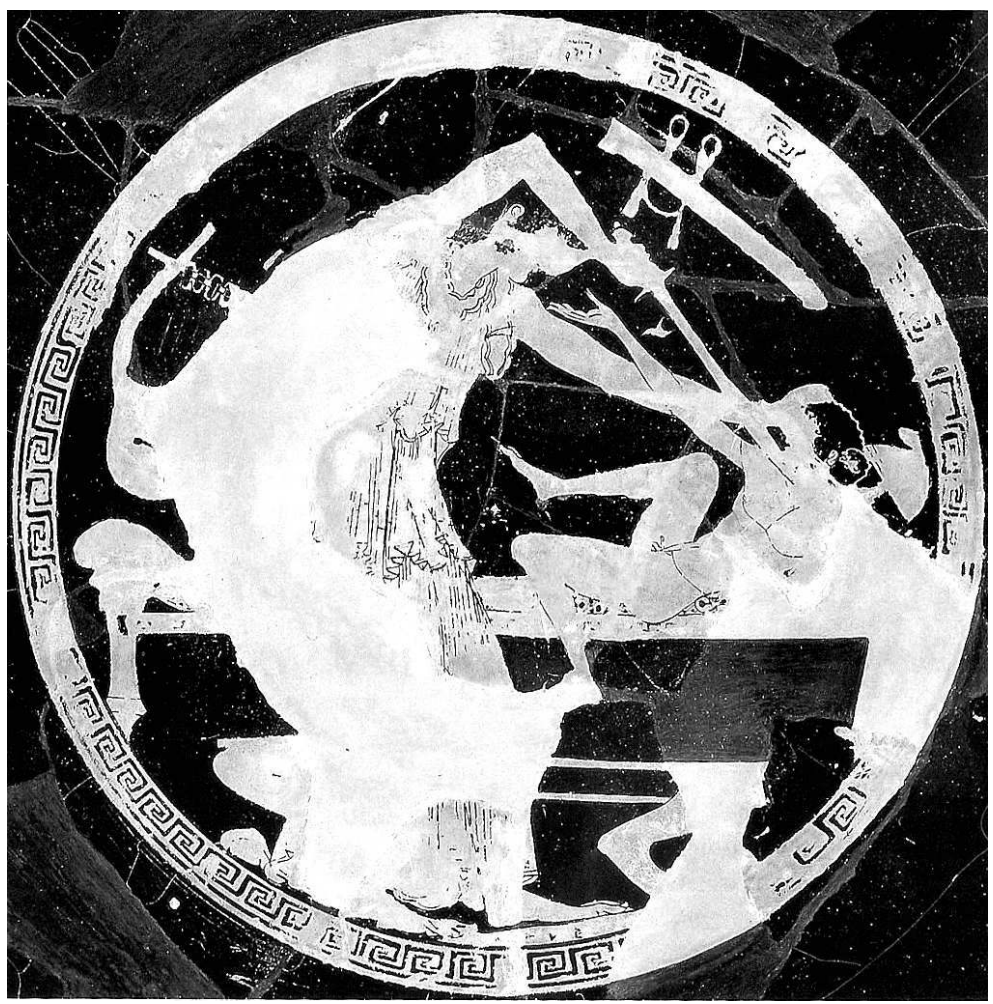

Att. rf. kylix, 510-500 BC, Magnoncourt-Painter, Munich 2638. 9191. @ Staatliche Antikensammlungen und Glyptothek München, photo: Renate Kühling

34 At first sight, it may appear that this story is perfectly suited to characterize women as evil creatures and to perpetuate the preconception of female anger and lack of self control. Indeed, this is exactly how Prokne and Philomela are characterized in early times. There are three late archaic cups that depict the gruesome event of the infanticide: on a kylix tondo in Munich (Fig. 10), ${ }^{33}$ Prokne (AE $\Delta$ ONAI) bends over her son Itys (ITY $\Sigma$ ) and rams her sword into his throat. She is looking grim and determined, while her son is lying on a klinê, struggling helplessly with his legs and raising his hand in a gesture of supplication. The dining couch and the lyra hanging from the wall in the background already allude to the dreadful meal Prokne is going to serve to her husband. The exterior of this drinking cup is decorated with an ecstatic thiasos of maenads and satyrs that often serves as visual counterpart to the self restrained and controlled conduct of male citizens. Thus, the whole image program of this drinking vessel is dominated by transgressive 
behavior. Images like this are all about presenting the gruesome and unmotherly nature of the heroine. ${ }^{34}$

Around $460 \mathrm{BC}$, Prokne sinks into oblivion until she gets newly discovered by Sophocles around 431-425 BC. In his now lost tragedy Tereus, he adds some decisive details to the old myth that result in a particular empathic view on the doom of the Athenian princess. In a surviving fragment (fr. 5, 1-12, transl. by H. Lloyd Jones), Prokne talks about the tragic lot of women and laments that she was married off to a complete stranger, a barbarian:

I have often regarded the nature of women in this way, seeing that we amount to nothing. In childhood in our father's house we live the happiest life, I think, of all mankind; for folly always rears children in happiness. But when we have understanding and have come to youthful vigor, we are pushed out and sold, away from our paternal gods and from our parents, some to foreign husbands, some to barbarians, some to joyless homes, and some to homes that are opprobrious. And this, once a single night has yoked us, we must consider to be happiness.

Fig. 11: Prokne and Itys

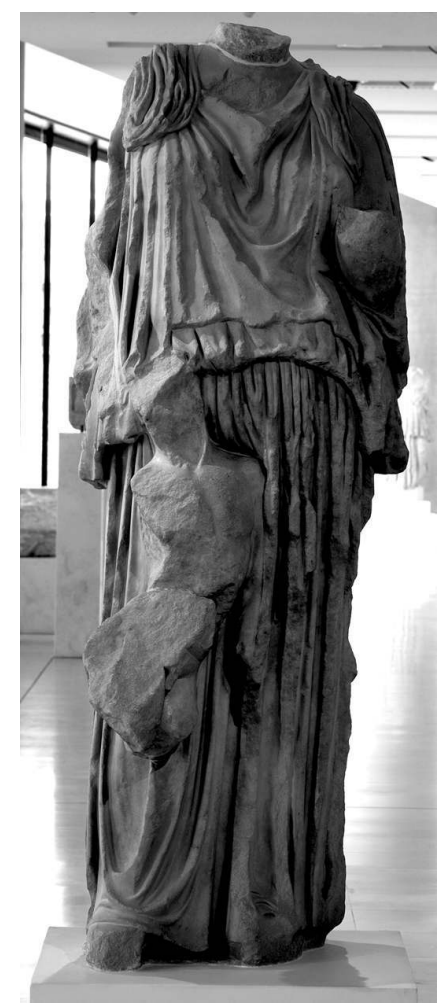

Marble by Alkamenes, 430-420 BC, Athens Akropolis Museum 1358. 2789. (c) Acropolis Museum photo: Socrates Mavrommates

The statement not only evokes sympathy for the wretched fate of women in general, it also implies that Prokne feels deprived of her right (and duty) to beget legitimate Athenian children. ${ }^{35}$ The passage thus hints at a reevaluation of the murdering mother towards an extreme yet heroic role model for Athenian women. Shortly after, around 420 BC, Alkamenes created a beautiful statue group showing Prokne and her little son Itys just before the murder (Fig. 11). ${ }^{36}$ The statue group, probably a private dedication by the artist himself, was erected on the Akropolis, along the north flank of the Parthenon and thus amidst all the divinities and eponymous heroes that populate Athens' venerable past. ${ }^{37}$ Prokne is wearing a heavy peplos that underlines her matronal appearance. Itys is hiding 
within the folds of his mother's garment and thus trying to seek refuge with his very murderess. The mother's head and arms are broken off, but she was probably holding her sword in the right hand and already pressing it against the throat of her little son. ${ }^{38} \mathrm{Her}$ left hand was probably brought to her slightly lowered head in a gesture of contemplation about her child's fate. Although the woman's face and arms are missing, this fine work of art still reveals a certain "natural intimacy" between mother and son by capturing Prokne's inner turmoil and Itys' staunch trust in her. Here too, one could propose that the historical circumstances led to a certain rehabilitation of the murdering mother. ${ }^{39}$ In any case, the story of Prokne and her Thracian husband now acquired a decidedly political meaning.

As in the case of Praxithea, this altered perspective on Prokne in both literature and sculpture becomes understandable only when considering the political climate in which these works were created. In the context of the Peloponnesian war, the Athenian claim for autochthony was stronger than ever, and so was the necessity to adopt an uncompromising attitude towards the enemies of Athens. While Praxithea sacrifices her own beloved child, the legitimate offspring of the Athenian king, to save the city from foreign rule, Prokne kills her own son, a "half-breed" with a Thracian father, in order to take vengeance on a barbarian and to restore the honor of her family, the royal family of Athens. Both actions, as brutal as they may appear, are direct deductions of a radically formulated claim for and defense of autochthony and national purity. In the times of political crisis, the disputable and ambivalent figures of Praxithea and Prokne were able to enter the collective memory of the Athenians as heroic citizen wives and mothers. In the new climate of self-sacrifice and nationalism, even a child-murderess becomes an epitome of selfless behavior.

\section{Closing Remarks}

This paper explored some of the ways in which maternal figures were characterized in the imagery of the Athenian Akropolis. The evidence clearly demonstrates that there was not just one way to think of maternity and motherhood in classical Athens: The figure of Ge embodied a purely biological conception of motherhood that becomes obsolete in the moment of birth. The kourotrophic figures on the Erechtheion frieze also conveyed a rather physical notion of maternity confined to the nourishment (trophê) of children. Athena, on the other hand, assumed the role of the mental attachment figure and thus served as a "social mother" for Erichthonios (and all his descendants). Praxithea impersonated self-restraint and emotional control by overcoming her maternal instincts in sacrificing her own child for the greater good. And the figure of Prokne demonstrated that even Athenian women were capable to fight with the greatest vigor against foreign perpetrators - even at the expense of their own children's life. Thus, Athenian myth is full of women that play a crucial role in the city's past by fulfilling "maternal roles": They serve as childbearers, foster mothers, social mothers, and nurses; they can be selfdetermined or devoted, vindictive or condoning.

Despite their manifold differences and sometimes even contradicting messages, these mothers and maternal figures share at least one crucial similarity: They were represented amidst the public realm of the Akropolis and thus formed an integral part of the political and religious center of the city. In these images, there is no evidence of marginalizing the 
female or excluding it from the political sphere. On the contrary: as far as the eye could reach on the Akropolis, the "maternal principle" was omnipresent.

\section{BIBLIOGRAPHIE}

Barringer J. M. (2005), “Alkamenes' Prokne and Itys in Context”, in Barringer J. M., Hurwit J. M. and Pollitt J. J. ed., Periklean Athens and Its Legacy. Problems and Perspectives, Austin, p. 163-176.

Baudy G. J. (1992), "Der Heros in der Kiste. Der Erichthoniosmythos als Aition athenischer Erntefeste", Antike und Abendland 38, p. 1-47.

Blok J. H. (2009), “Perikles' citizenship law: a new perspective”, Historia 58, 2, p. 141-170.

Boulter P. N. (1970), “The Frieze of the Erechtheion”, Antike Plastik 10, p. 7-28.

Brouskari M. (1988), “Z $\omega 1 \delta ı \alpha \Lambda \alpha ı \varepsilon \varepsilon$. Nouvelles figures de la frise de l'Érechtheion”, in Schmidt M. ed., Kanon. Festschrift Ernst Berger, Basel, p. 60-68.

Calame C. (2011), “Sacrifice des filles d'Érechthée et autochtonie. Fondations étiologiques dans l'Athènes classique", in Sebillotte Cuchet V. et Ernoult N. ed, Les femmes, le féminin et le politique après Nicole Loraux, Classics@ [En ligne] issue 7. URL : http://chs.harvard.edu/wa/pageR? $\mathrm{tn}=$ ArticleWrapper\&bdc=12\&mn=3826

Chazalon L. (2003), "Le mythe de Térée, Procné et Philomèle dans les images attiques”, Mètis N. S. 1, p. 118-148.

Clairmont C. (1971), “Euripides' Erechtheus and the Erechtheion”, GRBS 12, p. 485-495.

Connelly J. B. (1996), "Parthenon and Parthenoi. A Mythological Interpretation of the Parthenon Frieze”, AJA 100, p. 53-80.

Crelier M.-C. (2008), Kinder in Athen im gesellschaftlichen Wandel des 5. Jahrhunderts v. Chr. Eine archäologische Annäherung, Remshalden.

Curtius E. (1873), “Die Geburt des Erichthonios”, Archäologische Zeitung 30, p. 51-57.

Darthou S. et Strawczynski N. (2006), "Naissance, reconnaissance, légitimation : les gestes de la filiation dans la céramique attique”, in Bodiou L., Frère D. and Mehl V. ed, L'expression des corps. Gestes, attitudes, regards dans l'iconographie antique, Rennes, p. 49-59.

Daux G. (1968), “Chronique des fouilles et découvertes archéologiques en Grèce en 1967”, BCH 92, p. 711-1135.

Detienne M. (2003), Comment être autochtone. Du pur Athénien au Français raciné, Paris.

Dickmann J. A. (2006), “Adult's children or childhood gendered twice”, in Mattusch C. C.,

Donohue A. A. and Brauer A. ed., Common Ground: Archaeology, Art, Science, and Humanities, Oxford, p. 466-469.

Dillon M. (2002), Girls and Women in Classical Greece, London.

Fehr B. (2011), Becoming Good Democrats and Wives. Civic Education and Female Socialization on the Parthenon Frieze, Hephaistos Sonderband, Munich. 
Goette H. R. (2001), Athens, Attica, and the Megarid. An Archaeological Guide, London.

Hadzisteliou-Price Th. (1978), Kourotrophos. Cults and Representations of the Greek Nursing Deities, Leiden.

Holtzmann B. (2000), "Note sur la frise de l'Érechtheion. Le sujet de MAcr 1073”, BCH 124, p. 221-226.

Hurwit J. M. et Newton A. D. (2004), The Acropolis in the Age of Pericles, Cambridge.

Kaltsas N. (2002), Sculpture in the National Archaeological Museum Athens, Los Angeles.

Klöckner A. (2005), "Mordende Mütter. Medea, Prokne und das Motiv der furchtbaren Rache im klassischen Athen", in Fischer G. and Moraw S. ed., Die andere Seite der Klassik. Gewalt im 5. und 4. Jahrhundert v. Chr., Stuttgart, p. 247-263.

Korres M. (1988), “Acropole. Travaux de restauration”, BCH 112, p. 612.

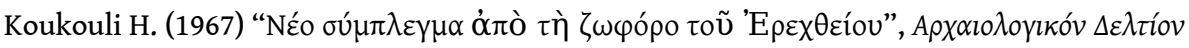

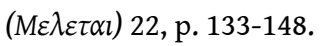

Kron U. (1976), Die zehn attischen Phylenheroen. Geschichte, Mythos, Kult und Darstellungen, Berlin.

- (1997), "Erechtheus", LIMC V, Zürich, p. 923-951.

Lesk A. (2004), A Diachronic Examination of the Erechtheion and its Reception, Cincinnati.

Lévêque P. (1992), “La naissance d'Érichthonios, ou de quelques distorsions dans la sainte famille”, REA 94, p. 315-324.

Loraux N. (1981), Les Enfants d'Athéna. Idées athéniennes sur la citoyenneté et la division des sexes, Paris.

- (1996), Né de la terre. Mythe et politique à Athènes, Paris.

Lorenz s. (2008), “Frauen von mörderischer Stärke”, in Wünsche R. ed., Starke Frauen. Expo München , München, p. 279-309.

March J. R. (2000), “Vases and tragic drama. Euripides' Medea and Sophocles' lost Tereus”, in Rutter N. K. and Sparkes B. A. ed., Word and Image in Ancient Greece, Edinburgh, p. 119-139

Metzger H. (1976), “Athéna soulevant de terre le nouveau-né. Du geste au mythe”, in Bögli H. and Martin C. ed., Mélanges d'histoire ancienne et d'archéologie offerts à Paul Collart, Paris, p. 295-303.

Monella P. (2005), Procne e Filomela. Dal mito al simbolo letterario, Testi manuali per l'insegnamento universitario latino 83, Bologna.

MorizotY. (2004), "Offrandes à Artémis pour une naissance. Autour du relief d'Achinos”, in Dasen V. ed., Naissance et petite enfance dans l'Antiquité, Fribourg, p. 159-170.

Pallat L. (1912), "The Frieze of the Erechtheum”, AJA 16, p. 175-202.

- (1935), “Der Fries der Nordhalle des Erechtheion”, JDAI 50, p. 79-137.

- (1937), “Zum Friese der Nordhalle des Erechtheion”, JDAI 52, p. 17-29.

Räuchle V. (2012), “Unmütterlichen Zornes verwirrt ? Zur wandelbaren Ikonographie der Kindsmörderin Prokne im Athen des 5. und 4. Jahrhunderts v. Chr.”, in Reinholdt C. and Wohlmayr W. ed., Akten des 13. Österreichischen Archäologentages. Klassische und Frühägäische Archäologie, Vienna, p. 153-160.

Reeder E. D. and Humphreys S. C. ed. (1995), Pandora. Women in Classical Greece. Expo Baltimore, Baltimore. 
Robert C. (1890), “Archäologische Nachlese”, Hermes 25, p. 412-450.

Rosivach V. J. (1987), “Autochthony and the Athenians”, CQ 37, 2, p. 294-306.

Sebillotte Cuchet V. (2005), "La terre-mère. Une lecture par le genre et la rhétorique patriotique", Kernos 18, p. 203-218.

Shapiro H. A. (1998), "Autochthony and the Visual Arts in Fifth-Century Athens”, in Boedeker D. and Raaflaub K. A. ed., Democracy, Empire, and the Arts in Fifth-Century Athens, Cambridge, p. 127-151.

- (2003), "Fathers and Sons, Men and Boys", in Neils J. and Oakley J. H. ed., Coming of Age in Ancient Greece. Images from Childhood in the Classical Past. Expo Hanover, New Haven, p. 84-111.

Smoke S. J. (2010), The Erechtheion. Deciphering the Fragments of the Ionic Frieze, an unpublished Thesis, Master of Arts, Louisiana State University. URN: etd-04272010-151828

Sourvinou-Inwood C. and Parker R. (2010), Athenian Myths and Festivals. Aglauros, Erechtheus, Plynteria, Panathenaia, Dionysia, New York.

\section{NOTES}

1. The earliest known source for Hephaestus chasing Athena is a now lost relief on the Amyclean throne created by Bathykles of Magnesia towards the end of the sixth century BC and described by Pausanias $(3,18,13)$. It is not before Euripides ( $\operatorname{TrGF} 5 \mathrm{~F} 925)$ that we have a written record of this episode; cf. Apollodorus 3, 14, 6 .

2. The basic features of the earthbirth of Erichthonios/Erechtheus as well as his upbringing by Athena are already told by Homer, Il. 2, 546-549 (transl. by S. Butler): "[...] And they that held the strong city of Athens, the dêmos of great Erechtheus, who was born of the soil itself, but Zeus' daughter, Athena, fostered him, and established him at Athens in her own rich sanctuary". - oî

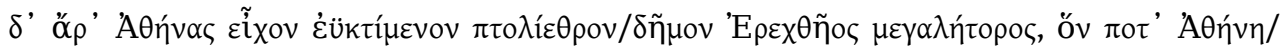

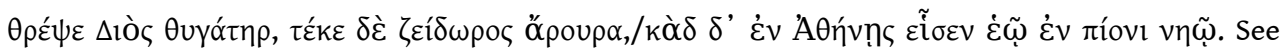
also Homer, Od. 7, 78-81; cf. Kron 1997, 925; Sourvinou-Inwood 2010, p. 38-39.

3. The earliest account for the Kekropids as nurses of Erichthonios is Euripides' Ion (267-274); see also Apollodorus 3, 14, 16; Pausanias 1, 18, 2; cf. Sourvinou-Inwood 2010, p. 37-38. On the complex connection between the Kekropids and the cult service of the arrhephoroi see Baudy 1992, p. 5-25.

4. There is a consensus, however, that the splitting into two distinct personalities took place in the second half of the fifth century $\mathrm{BC}$ and thus the period in which most attic vase paintings of Erichthonios' birth were produced. - For a still valid evaluation of ancient written and pictoral sources see Kron 1997, esp. p. 923.927 (with further literature); Sourvinou-Inwood 2010, p. 51-89, here 88: "As we saw, in Athenian eyes there was only one hero Erechtheus; in the earlier versions of Athenian mythology he was a primordial king, earthborn and the nursling of Athena; after Erichthonios was constructed and had taken over the mythemes that had made up the unambiguously primordial facet of Erechtheus, Erechtheus eventually morphed into the persona focused on the war against the Eleusinians and the sacrifice of his daughters".

5. The strong presence of Erichthonios in the visual arts with his simultaneous underrepresentation in the written sources is even alluded to in a passage in Euripides' Ion in which the hero interrogates his not yet recognized mother about her ancestry, Euripides, Ion 267-272 (transl. by R. Potter): “Ion: Your father's ancestor grew from the earth?/Creusa: Yes, Erichthonius; but my family is no benefit to me./Ion: And did Athena take him up from the earth?/Creusa: Into her virgin hands; she was not his mother./Ion: And gave him, as paintings

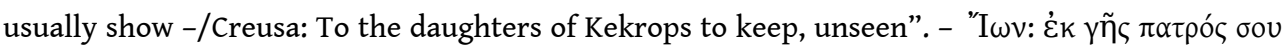




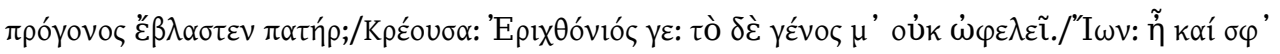

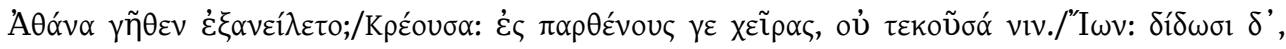

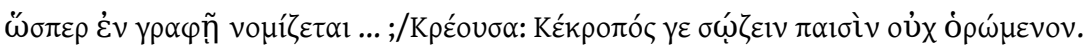

6. This number is based on the collection of vase paintings in LIMC, see Kron 1997, p. 928-931, $\mathrm{n}^{\circ}$. 1-17: 1.) Att. bf. wgr. lekythos, 500-480 BC, Palermo Coll. Mormino 769. - 2.) Five bf. loutrophoi (fragments), 450-400 v. Chr., Athens Akropolis Museum 1188-1192. 1195. -3.) Att. rf. hydria, ca. 470-460 BC, London BM E 182; ARV 580, 2; - 4.) Att. rf. pelike, 470-460 BC, Leipzig T 654; ARV² 585, 35. - 5.) Att. rf. pelike, Athens Agora P 18411; $A R V^{2}$ 588, 87. - 6.) Att. rf. stamnos, 460-450 BC, Munich 2430; Para 380. - 7.) Att. rf. kylix, 440-430 BC, Berlin F2537. - 8.) Att. rf. squat lekythos, 420-410 BC, Cleveland CMA 82.14. - 9.) Att. rf. squat lekythos, 425-400 BC, Athens NM A 21903; ARV 2 1314, 15. - 9a.) Att. rf. pyxis (lid), 425-400 BC - 10.) Att. rf. calyx krater, end of fifth cent. BC, Adolphseck 77; $A R V^{2}$ 1346, 1. - 11.) Att. rf. calyx krater, end of fifth cent. BC, Richmond 81.70. - 12.) Att. rf. calyx krater, end of fifth cent. BC, Palermo Mus. Reg. 2365; ARV $221339,3$.

7. Att. bf. wgr. lekythos, early fifth century BC, Palermo Coll. Mormino 769; Kron 1997, $928 \mathrm{n}^{\circ}$. 1.

8. A more detailed interpretation of these "supporting characters" can be found in Shapiro 1998, p. 132 .

9. Att. rf. hydria, 470-460 BC, British Museum E 182, BA n² 206695; ARV 2 580, 2; CVA London, British Museum (6) pl. 85,1a-b; Reeder 1995, p. 254-255, nº 67.

10. Att. rf. kylix, 440-430 BC, Codrus painter, Berlin SMPK F 2537, from Tarquinia; BA $\mathrm{n}^{\circ}$ 217211; $A R V^{2}$ 1268.2. 1689; CVA Berlin (3) 13-14, pl. 113,1-2. 115,2. 116,2. 117,1. 132,4. 8; Kron1976, pl. 4,2. 5,2; Reeder 1995 , p. 258-260, $\mathrm{n}^{\circ}$ 70. Side A depicts Athena, Ge and Erichthonios in center surrounded by Kekrops, Hephaistos and a woman (Pandrosos?); side B lines up further spectators of the birth (Athenian kings and the kekropids). The tondo shows the abduction of Kephalos by Eos.

11. Metzger 1976, p. 302: "Sous l'aspect poétique et légendaire qui plaît tant aux imagiers grecs il s'agit sans doute, comme l'avait déjà pressenti E. curtius, de l'illustration d'un rite athénien de la naissance. L'usage est attesté à Rome pour le personnage de Levana: l'enfant a été déposé à terre, Levana le soulève et le confie à sa famille. Athéna jouerait sur nos monuments le rôle de la 'lévatrice' romaine; ce rôle s'expliquerait d'autant mieux dans le cas d'Érichthonios que le héros athénien est censé être né de la Terre".

12. Att. rf. skyphos, around 450 v. Chr., Wien KHM 1773; BA n 213234; ARV ${ }^{2}$ 972, 2; CVA Wien (1), 31-32. pl. 39 1-2; Shapiro 2003, p. 95. Father Theseus (...ఠとטৎ) is featured on the other side of the vase; he is wearing a mantle, petasos and spears and is bidding farewell to Athena.

13. Votive relief of Xenokrateia, around 410 BC, Athens NM 2756, from Attika; Kaltsas 2002, 133 Abb. 257; Dillon 2002, p. 25; Kron 1996, p. 128. The corresponding inscription (IG II ${ }^{2} 4548$ ) reads:

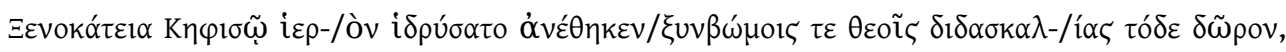

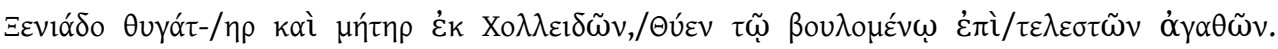
- "Xenokrateia, daughter and mother of Xeniades,/from Cholleidai, founded the sanctuary to Kephisos/and dedicated this gift to the gods who share the altar/for his and their teaching;/ sacrificing is permitted for those wanting fulfillment" (transl. by D. Schneller). - A similar motif can be found on the Echinos relief to Artemis, around $300 \mathrm{BC}$, Lamia Archaeological Museum AE 1041, from Echinos; Morizot 2004, esp. p. 160, fig. 1.

14. The single elements of the interaction pattern - i.e. longing, receiving and carrying - occur in different combinations. Six vase paintings show the sitting mother receiving the longing child carried by an attendant: 1.) att. rf. lekythos, 475-450 BC, Athens NM 1304; BA n 9025010; Crelier 2008, 126. $264 \mathrm{n}^{\circ}$ L4. - 2.) att. wgr. lekythos, 460-450 BC, Berlin SMPK F2443; BA n 213940; ARV 2 995.118. 1567; Crelier 2008, p. 126. $264 \mathrm{n}^{\circ}$ L3. - 3.) att. wgr. lekythos; 470-460 BC, Athens NM 12771; $\mathrm{BA}^{\circ}$ 209182; $A R V^{2}$ 743. 1668; Crelier 2008, p. 127. $244 \mathrm{n}^{\circ}$ L6. - 4.) att. wgr. oinochoe, 460-450 BC, New York Sotheby's; BA $n^{\circ} 31854$. -5.) att. rf. kalpis, around 450 BC, London BM E 219; BA n ${ }^{\circ}$ 
217063; $A R V^{2}$ 1258.3; Crelier 2008, p. 197. $262 \mathrm{n}^{\circ}$ H2. - 6.) att. wgr. lekythos (fr.), around $440 \mathrm{BC}$, London BM 1905.7-10.10; BA n 216338; ARV ${ }^{2}$ 1227.10; Crelier 2008, p. 145. $272 \mathrm{n}^{\circ}$ L41. - Another six versions depict a sitting, crouching or standing boy who stretches out his arms for the mother who is in turn making a welcoming gesture: 1.) att. rf. kylix, around $460 \mathrm{BC}$, Bruxelles MRAH A890; $B A n^{\circ}$ 209536; $A R V^{2}$ 771.1; Crelier 2008, p. 192. $263 \mathrm{n}^{\circ} \mathrm{K} 1 .-2$.) att. rf. pelike; 430-420 BC, London British Museum E396; BA $n^{\circ}$ 215016; $A R V^{2}$ 1134.6; Crelier 2008, p. 196. $275 \mathrm{n}^{\circ}$ Pe1. - 3.) att. rf.

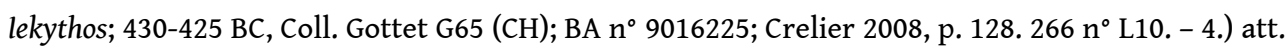
rf. lekythos; around 420 BC; Palermo Coll. Banco di Sicilia 1606; BA n ${ }^{\circ} 7853$; Crelier 2008, p. $266 \mathrm{n}^{\circ}$ L11. - 5.) att. rf. pyxis, around $460 \mathrm{BC}$, Athens NM 1623; BA n 275745; Crelier 2008, p. 185. $274 \mathrm{n}^{\circ}$ P2. - 6.) att. rf. kylix, 470-460 BC, Berlin SMPK 4282; BA n 207491; ARV ${ }^{2}$ 644.134; Crelier 2008, p. 192. $263 \mathrm{n}^{\circ} \mathrm{K} 2$. --- Only once the woman holding the child can be identified as the mother while the child is longing for the nurse: 1.) att. rf. kalpis; around $430 \mathrm{BC}$; Cambridge Sackler Museum 1960.342; BA nº 8184; Crelier 2008, p. 197. 262 n H3.

15. Att. rf. lekythos, 475-450 BC, Athens NM 1304; BA n 9025010; Crelier 2008, p. 126. 264 n $^{\circ}$ L4.

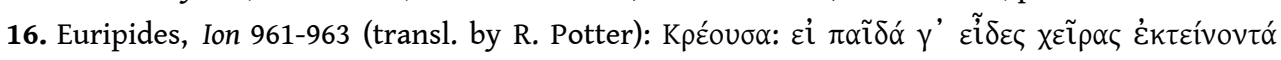

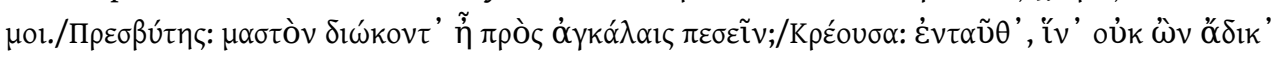

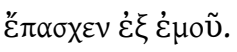

17. A similar interpretation was offered by Sonia Darthou and Nina Strawczynski who describe the genealogy of Erichthonios - as expressed through the images of his birth - as a double filiation, Darthou et Strawczynski 2006, p. 55: “Mais cette position médiane montre surtout qu'il $\mathrm{y} a$, dans cette naissance, une double filiation, mise en scène comme une transmission : le geste des bras tendus - qui élèvent pour Gè et qui reçoivent pour Athéna - exprime parfaitement la transmission entre une mère plus 'biologique' et une mère plus 'politique et 'sociale' - Athéna exprime ici davantage l'accueil qu'une 'tendre maternité' ".

18. The completion of the building in the year $407 / 06 \mathrm{BC}$ is documented by the building account IG $\mathrm{I}^{2}$ 474-479; cf. Goette 2001, p. 27. On the start of construction works around $438 \mathrm{BC}$ see Korres 1988; Korres 1997, p. 243, note 99; cf. Goette 2001, p. 27-28; Hurwit 1999, p. 206, note 128. An overview over alternative datings can be found in Lesk 2004, p. 64-71.

19. The main obstacle is that the frieze was executed in a rather exceptional technique: Instead of carving the frieze directly out of the marble slabs, the figures were carved separately and then attached onto dark Eleusinian limestone by means of iron dowels. Due to this exceptional technique the single pieces were scattered among the Akropolis over the millenia and completely detached from their original context.

20. Most of these attempts concentrate on the larger and probably more important part of the frieze on the North porch and are very hypothetical.

21. Suckling kourotrophos (nymph and Dionysos?), att. plastic lekythos, 4th century BC, from Corinth, Hadzisteliou-Price 1978, p. 36, n² 293, fig. 25. Other examples ibid, .

22. Robert 1890, p. 436; cf. Hurwit 1990, p. 208: "The prevalence of horses and chariots in the [building accounts] and the predominance of women in the extant fragments raises the possibility that at least some of the frieze represented the career of Erechtheus himself".

23. Joan Connelly argues instead that the story of Erechtheus was alluded to in the center piece of the eastern frieze of the Parthenon: Connelly 1996.

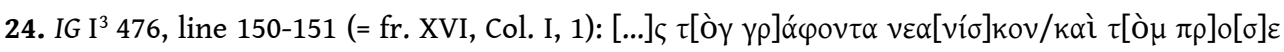

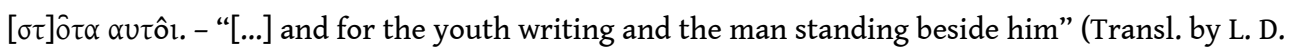
Caskey).

25. The youth bends over his left knee and looks downwards; his arms are now missing but can be easily reconstructed as stretched forward, holding a tablet and writing; cf. Robert 1890, p. 438; Holtzmann 2000, p. 223-224.

26. Robert 1890, p. 438: "Die Übereinstimmung dieser Figur mit dem jugendlichen Begleiter des Aleos auf dem pergamenischen Telphosfries legt die Erklärung nahe; jene Figur, die zwar nach 
der anderen Seite gewandt ist, aber in Stellung und Haltung die größte Ähnlichkeit zeigt, ist [...] im Begriff, ein von Apollo, vor dessen Statue sie kniet, er- theiltes Orakel aufzuzeichnen. Danach wird man die gleiche Thätigkeit auch für den knieenden Jüngling des Erechtheionfrieses voraussetzen und das Fragment mit [der Inschrift] identificiren dürfen. Man wird aber noch weiter gehen und fragen müssen, ob es nicht auch hier ein Orakel ist, das aufgezeichnet wird".

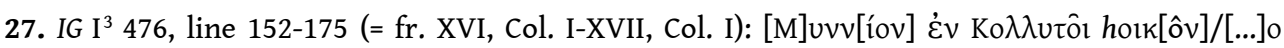

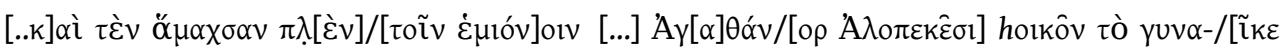

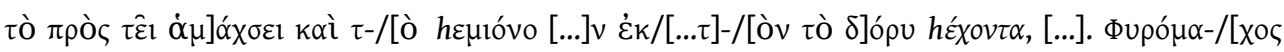

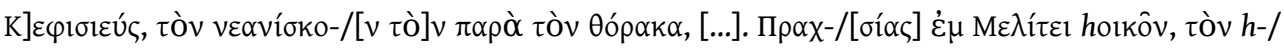

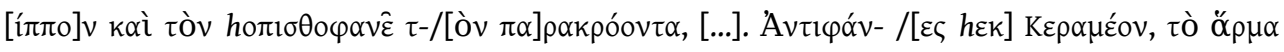

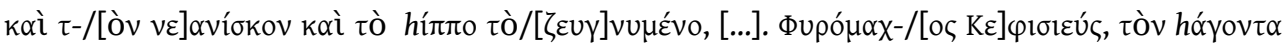

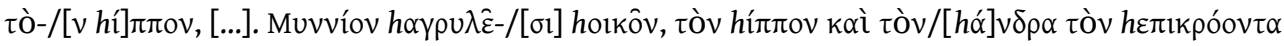

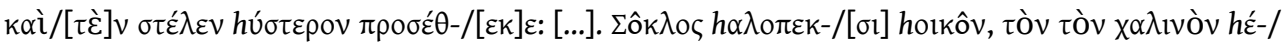
$[\chi 0] v \tau \alpha,[\ldots]$.

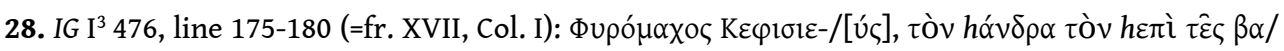

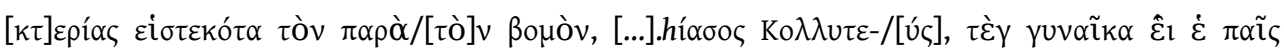

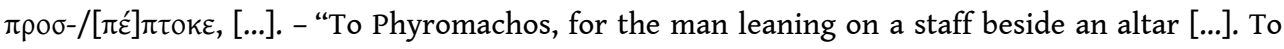
Iasos, for the woman with the little girl leaning against her, 80 drachmae" (Transl. by L. D. caskey ) .

29. See Daux 1968, p. 721, fig. 1. A close examination of the fragment clearly shows that the girl's feet were not reaching the ground. She therefore had to cling onto the woman's shoulders to maintain her position.

30. Even the vicious murderess Clytemnestra laments in Sophocles' Electra 771-772: “There is a terrible power in giving birth; a mother may be wronged,/But she can feel no hatred for those whom she bore" (Transl. by R. Jebb).

31. Joan Connelly develops a comparable line of argument for the decoration of the Parthenon. She claims that the center piece of the Eastern frieze depicted the royal family - Erechtheus, Praxithea and their daughters - in the moment before the sacrifice Alas, the iconographic evidence for such a claim is rather weak. See Connelly 1996.

32. For a detailed discussion on different versions in the literary tradition see: Monella 2005.

33. Att. rf. kylix, 510-500 BC, Magnoncourt-Painter, Munich 2638. 9191; BA nº 212468.

34. On the vase paintings of Prokne, Philomela and Itys see March 2000; Chazalon 2003; Räuchle 2012.

35. On the citizen law of the year 451-450 BC by Perikles: [Aristoteles], Athenaion Politeia 26, 4; cf. Blok 2009.

36. Prokne and Itys, marble group by Alkamenes, Athens Akropolis Museum 1358. 2789; identification on the basis of Pausanias 1, 24, 3; latest studies (with discussion of older references): Barringer 2005; Klöckner 2002, p. 247-263; Räuchle 2012, p. 157-158.

37. On the exact position of the group and its "part of a play of resonant images in the Periklean and post-Periklean Akropolis" see Barringer 2005, p. 168-169.

38. Her elevated right shoulder as well as her bulged biceps are indicating this reconstruction, see Knell 1978, p. 13; cf. Barringer 2005, p. 165: "I think we might go further and consider the possibility that Procne actually held the sword to her son's throat, rather than simply gripping the knife, while Itys, anxiously into his mother's skirts and drawing this drapery toward him with his left hand, gazed up his mother".

39. For a similar reading of the statue group see Barringer 2005; Lorenz 2008 ; Klöckner 2002, p. 261: Anscheinend bilden die Erfahrungen des Peloponnesischen Krieges den Hintergrund, vor dem in Athen eine Haltung an Aktualität gewinnt, die die Ansprüche des Kollektivs über alles stellt und bei der letztendlich der Zweck die Mittel heiligt". 


\section{RÉSUMÉS}

Dans la recherche féministe, l'autochtonie a été interprétée comme le produit d'un système patriarcal et donc comme un concept particulièrement androcentrique. Selon Nicole Loraux, la terre-mère, dans sa capacité de produire des Athéniens, a été utilisée pour débarrasser les Athéniens de l'autre sexe et de sa fonction reproductrice. Ce n'est que récemment que les chercheurs ont abandonné cette interprétation dichotomique en faveur d'une perspective plutôt pragmatique. Cet article examine le problème d'un point de vue archéologique. L'analyse des images mythiques peut montrer que les figures maternelles jouent un rôle important dans la construction de l'identité civique des Athéniens. Ces images ne témoignent pas seulement de l'importance croissante de l'autochtonie, mais aussi d'un nouveau discours sur la maternité. Il semble que, pour la première fois dans l'histoire athénienne à l'époque classique, la maternité ait acquis une dimension résolument politique.

In feminist scholarship, the Athenian claim for autochthony has sometimes been interpreted as a product of the patriarchic system and therefore as a decisively androcentric perspective. According to Nicole Loraux, the earth goddess Ge was used to rid the Athenians of the female sex and their reproductive function. It is only recently that scholars have given up this dichotomous interpretation in favour for a rather pragmatic perspective. This article tackles the issue from an archaeological point of view: the analysis of selected images will demonstrate that maternal figures play a prominent role in the construction of Athenian civic identity. These images not only testify the increasing importance of autochthony but also point to a new discourse on motherhood. It can be argued that, for the first time in classical Athenian history, motherhood obtained a decidedly political dimension.

\section{INDEX}

Mots-clés : autochtonie, maternité, iconographie, céramique, sculpture, Acropole, Gê, Érichthonios, Érechthée, Praxithéa, Procné

Keywords : Athena, motherhood, iconography, vase painting, sculpture, Akropolis, Ge, Erichthonios, Erechtheus, Praxithea, Prokne

\section{AUTEUR}

\section{VIKTORIA JOHANNA RÄUCHLE}

Institut für Klassische Archäologie, Universität Wien 